\title{
Betekintés a Kúria joggyakorlat-elemző munkacsoportjának munkájába
}

\section{Insight into the work of jurisprudence analysing working groups at the Kúria (Supreme Court of Hungary)}

\author{
Somogyi Gábor \\ Dr. tanácselnök, \\ Kúria, \\ Büntető Kollégium \\ somogyi@birosag.hu
}

\begin{abstract}
Absztrakt
Cél: A szerző a Kúria emberkereskedelem bírói értelmezését vizsgáló joggyakorlat-elemző csoportjának vezetőjeként a joggyakorlat-elemző csoport munkájának bemutatására vállalkozik.

Módszertan: A tanulmány első részében a vizsgálat tárgyának megjelölése mellett a csoport megalakulása és eddigi munkája kerül bemutatásra. Részletezésre kerül a megalakulás körülményei a váratlanul kitört COVID-19-világjárvány közepette, és miképp érintette a csoport munkáját az a nem mindennapos tény, miszerint a megalakulást követően igen röviddel a vizsgálat tárgyát képező jogterület jogi szabályozása teljes egészében megváltozott.

Megállapítások: Az írás második részében mintegy a joggyakorlat-elemző csoport hipotéziseként részletesen írás olvasható az emberkereskedelem törvényi tényállásának és bírói gyakorlatának változásairól, választ keresve arra a kérdésre, hogy milyen nehézségek jelentkeztek rendszerszinten az emberkereskedelem beiktatásával a jogalkalmazásban, hogyan ütköztek az e címen büntetni rendelt magatartások más, a magyar jogrendszerben mélyen gyökerező törvényi tényállásokkal, milyen megoldásokat keresett a jogalkalmazó és a jogalkotó e problémák feloldására, és mi várható a jogalkalmazásban az emberkereskedelem törvényi tényállásának legutóbbi, teljes átstruktúrálását követően.

Érték: A Kúria joggyakorlat-elemző csoport munkájának bemutatásán keresztül kutatás olvasható az emberkereskedelem törvényi tényállásának és bírói gyakorlatának változásairól.
\end{abstract}

Kulcsszavak: Kúria, joggyakorlat-elemzés, emberkereskedelem, élősdi büncselekmények 


\section{Abstract}

Aim: The author undertakes to present the work of the case law analysis group as the leader of the jurisprudence analysing group by examining the judicial interpretation of human trafficking of the Supreme Court.

Methodology: In the first part of the study, in addition to indicating the subject of the study, the formation and work of the group so far are presented. The circumstances of the formation in the midst of the unexpected COVID pandemic and how the group's work was affected by the unusual fact that the legal regulations of the area under investigation have changed completely shortly after its formation are detailed.

Findings: In the second part of the paper, as a hypothesis of the jurisprudence analysis group, a detailed article is written on the changes in the legal situation and judicial practice of trafficking in human beings, answering the question of systemic difficulties in enforcing with other legal facts deeply rooted in the Hungarian legal system, what solutions did the law enforcer and the legislator seek to solve these problems and what can be expected in the application of the law after the last, complete restructuring of the legal facts of human trafficking. Value: Through the presentation of the work of the Suprem Court's case law analysis group, research on changes in the legal facts and judicial practice of human trafficking can be read.

Keywords: Supreme Court, case law analysis/ jurisprudence analysis group, human trafficking, parasitical crimes

\section{A joggyakorlat-elemző csoport vizsgálatának tárgya és a csoport eddigi munkája}

2020. évre a Kúria elnöke a joggyakorlat-elemzés egyik tárgyköreként az emberkereskedelem értelmezésével kapcsolatos bírói gyakorlatot határozta meg. A döntést indokolta, hogy az emberkereskedelem az elmúlt bő két évtizedben „hányattatott” sorsú jogintézmény volt, miközben a mögötte meghúzódó társadalmi jelenség egyre feszítőbb problémaként jelentkezett nemzetközi szinten, és egyre inkább Magyarországon is (URL1).

A Btk. Különös Részébe 1999-ben beiktatott emberkereskedelem közel húsz évig nem nagyon találta a helyét a jogalkalmazásban, avagy a jogalkalmazás nem tudott mit kezdeni az új tényállással. (Ennek okairól később részletesen írok). 2019 májusától azonban úgy látszott, hogy megmozdult az állóvíz, és áttörés következhet be az emberkereskedelmi ügyek megítélésében. 
A Legfőbb Ügyészség már 2018. október 25-én új iránymutatást adott ki az emberkereskedelem ügyészi megítélése kapcsán, majd az ennek alapján emelt ügyészségi felülvizsgálati indítványok nyomán a Kúria több határozatot hozott, amelyekben kerítés, illetve kényszermunka büntette miatt kiszabott jogerős ítéleteket helyezett hatályon kívül, és utasította az illetékes törvényszékeket új eljárás lefolytatására azzal az indokkal, hogy a más büncselekményként elbírált cselekmények helyes minősítése valójában emberkereskedelem büntette. E határozatok nem csupán azért hatottak a meglepetés erejével a jogalkalmazókra, mert olyan magatartások kapcsán világított rá arra, hogy azok valójában emberkereskedelemnek minősülnek, amelyeket korábban a bíróságok „,rutinszerüen” bíráltak el más büncselekményként, de azért is, mert teljesen új szempontrendszert alkalmaztak e magatartások elbírálása során. Erről is a későbbiekben szólunk majd. A fentiekből kitünik, hogy volt oka a Kúria elnökének az emberkereskedelem értelmezése bírói gyakorlatának vizsgálatát 2020-ra a joggyakorlat-elemzés egyik tárgyköreként meghatározni. A legnagyobb rendező azonban mindig az élet: a döntést követően néhány héten belül - még mielőtt a joggyakorlat-elemző csoport megalakulhatott volna - két egymást követő napon két olyan esemény történt, ami alapjaiban kihatott a csoport előtt álló elvégzendő feladatokra, és a munkavégzés kereteit is meghatározta.

2020 elején váratlanul tört a világra a COVID-19-világjárvány, s 2020. március 11-én a magyar kormány is veszélyhelyzetet hirdetett ki. Noha a hírekben már hallhattuk, miképp terjed a járvány világszerte, bármiféle ezirányú tapasztalat hiányában nem nagyon tudtuk elöre felmérni, hogyan befolyásolhatja egy ilyen helyzet a mindennapi életünket, beleértve a munkavégzést is, és milyen hatása lesz mindennek jelesül a joggyakorlat-elemzésre. A telekommunikációs eszközökkel való kapcsolattartás kereteinek kiépítése még az egyes bírósági szerveken belül is időt vett igénybe, nem is szólva a szervezeten kívüli kapcsolattartásról. Az is nyilvánvaló volt, hogy miközben a bíróságok és a bírák hatalmas erőfeszítéseket tettek az igazságszolgáltatási alapfeladataik ellátására, a törvényszékek és az itélőtáblák nem voltak terhelhetők a joggyakorlat-elemző csoport munkájához elengedhetetlen adatolások és ügyválogatások elvégzésével.

Mindez oda vezetett, hogy a joggyakorlat-elemző csoport csak 2020. szeptember 18-án tudott - a járvány két hulláma között, de a tagok személyes részvétele mellett - megalakulni, és a visszatérő újabb és újabb hullámok kisebb-nagyobb mértékben folyamatosan hátráltatták a csoport munkáját.

A veszélyhelyzet kihirdetése elött egyetlen nappal egy másik olyan esemény is történt, ami talán még a világjárványnál is nagyobb hatással volt a csoport munkájára. Az Országgyülés 2020. március 10-i ülésnapján fogadta el az emberkereskedelem áldozatainak kizsákmányolása elleni fellépés érdekében szükséges 
egyes törvények módosításáról szóló 2020. évi V. törvényt, melynek 9. §-a 2020. július 1-jei hatállyal teljes mértékben átszabta a Btk. emberkereskedelemre vonatkozó szabályozását. A joggyakorlat-elemző csoport megnevezéséből adódik, hogy bár összefoglaló véleménye alapján a Kúria kollégiumvezetője jogegységi eljárást indítványozhat, vagy jogalkotás kezdeményezése érdekében a Kúria elnökén keresztül az OBH elnökéhez fordulhat ${ }^{1}$, elsődleges feladata a meglévő, az országban ténylegesen kialakult bírói gyakorlat vizsgálata. Kialakult bírói gyakorlatról pedig csak akkor beszélhetünk, ha annak alapja legalábbis viszonylag stabil joganyag; a módosult jogszabály - különösen, ha a módosítás jelentős - szükségszerüen vonja maga után a jogi értékelés változását anélkül, hogy a bírói gyakorlat változásáról beszélhetnénk. A szóban lévő törvényváltozás az emberkereskedelem terén igen jelentős; a törvényhozó teljesen új, a korábbitól eltérő koncepció mentén, új tényállási elemek meghatározásával ragadta meg a büntetendő, társadalomra veszélyes jelenséget, ami nyilvánvalóan új problémákat vet majd fel, és új megközelítést, szemléletet igényel majd a jogalkalmazótól is. Ez a helyzet egyúttal új, korábban soha nem látott követelményeket állított a joggyakorlat-elemző csoport elé is. Korábban soha nem fordult elő még, hogy kúriai joggyakorlat-elemző csoport olyan jogterületet vizsgált, aminek az alapjait meghatározó jogi szabályozást a joggyakorlat-elemző csoport megalakulásával szinte egyidőben gyökeresen megváltoztatták.

El kellett tehát döntenünk, mit teszünk ebben a helyzetben. Az világos volt, hogy bármennyire húzódik is az ismertetett okok folytán a joggyakorlat-elemző csoport összefoglaló véleményének elkészülése, annyi idő nem telhet el, hogy a törvényváltozás joggyakorlatot érintő hatását empirikus módon - az új törvény alapján meghozott határozatok elemzése útján - fel tudjuk mérni. Az új szabályozás jórészt szigorúbb a korábbinál, ezért nem várható nagy számban, hogy a bíróságok a Btk. 2. § (2) bekezdése alapján - a terheltre kedvezőbb elbírálás okán - már folyamatban lévő ügyekben, a hatályba lépését megelőzöen elkövetett cselekményekre alkalmazzák. Következésképp az új szabályok a gyakorlatban szinte kizárólag a 2020. július 1-je után elkövetett cselekmények esetében lesznek majd alkalmazhatók; az idevágó cselekmények nyomozásának és elbírálásának időigényességét figyelembe véve nem feltételezhető, hogy a csoport müködésének ideje alatt nagy számban születnek meg jogerős ítéletek, kúriai gyakorlat kialakulása pedig felülvizsgálati ügyek kapcsán még egyáltalán nem várható.

Ezért jutottunk arra a következtetésre, hogy a korábbi jogszabályokon alapuló gyakorlat feltárásával meg kell találnunk azokat a kapcsolódási pontokat,

1 A bíróságok szervezetéről és igazgatásáról szóló CLXI. törvény 30. § (2) bekezdés. 
amelyek az új törvény alkalmazása során is jelentőséggel lehetnek. A csoport vizsgálati szempontjait, munkamódszerét alapvetően ez határozta meg.

\section{A csoport megalakulása}

A Kúria elnöke a joggyakorlat-elemző csoport vezetőjévé dr. Somogyi Gábor kúriai bírót (2020. december 1. napjától: tanácselnök), tagjaként dr. Molnár Gábor Miklós kúriai tanácselnököt, valamint dr. Krecsik Eldoróda, dr. Gimesi Ágnes és dr. Bartkó Levente kúriai bírókat jelölte ki. A csoport vezetője a vizsgálat teljessége és a megfelelő müködés érdekében úgy tett javaslatot a külső tagok meghívására, hogy közöttük valamennyi, az emberkereskedelem elbírálásában részt vevő bírósági szint képviselve legyen. Rajtuk kívül javasolta az emberkereskedelem kriminológiai, szociológiai jellemzőit vizsgáló szakember felkérését is a csoport munkájában való részvételre.

Ennek megfelelően a Kúria Elnöke a joggyakorlat-elemző csoport munkájába bevonta dr. Elek Balázst, a Debreceni Ítélőtábla büntetőkollégium-vezetőjét, dr. Szabó Juditot, a Fővárosi Törvényszék mb. büntetőkollégium-vezetőjét, dr. Somogyi Zoltánt, Győri Törvényszék büntetőkollégium-vezetőjét, dr. Székely Gabriella fővárosi törvényszéki tanácselnököt, dr. Ignácz György fővárosi törvényszéki bírót és dr. Windt Szandrát, az Országos Kriminológiai Intézet tudományos főmunkatársát. Utóbb került bevonásra az Igazságügyi Minisztérium részéről dr. Jancsó Gábor főosztályvezető (jelenleg már helyettes államtitkár), valamint dr. Gellén Márton, majd a későbbiekben helyette dr. Mázi András helyettes államtitkár.

Amint arról korábban már szó volt, a csoport alakuló ülésére 2020. szeptember 18-án, a tagok személyes részvétele mellett került sor.

Dr. Molnár Gábor Miklós kúriai tanácselnök és dr. Krecsik Eldoróda kúriai bíró 2020. szeptember 30-ával nyugállományba vonult, a csoport munkájában azonban továbbra is aktívan részt vesznek.

\section{A csoport hipotézisei és eddigi munkája}

Az emberkereskedelem a Btk. Különös Részben meghatározott törvényi tényállás, ami mögött azonban az egész világra kiterjedő társadalmi jelenség húzódik meg. Az emberkereskedelem, elsősorban a nő- és a gyermekkereskedelem, az 1990-es évek óta az egyik legaggasztóbb jelenség a világban. Az emberkereskedelem a világ egyik legnagyobb és leggyorsabb ütemben növekvő bünözői iparága. Emberek millióit tartják rabszolgakörülmények között gyárakban, farmokon, otthonokban. Az utazás egyre gyorsabbá és egyszerübbé válása, 
valamint az olyan új technológiák, mint az internet egyre szélesebb körü elterjedése következtében az emberkereskedelem egyre nagyobb méreteket ölt, a 21. század első éveiben az egyik leggyakrabban felmerülő témakörré vált az emberi jogok területén. Ehhez képest az emberkereskedelem büncselekménye önálló törvényi tényállásként csak 1999. március 1 . napjától része a magyar jogrendszernek, ami azonban nem jelenti azt, hogy az ide tartozó cselekmények többségében más címen ne lettek volna büntethetők. Kétségtelen ugyanakkor, hogy emberkereskedelem miatt igen kevés ügyben jártak el a bíróságok, amit jól mutat, hogy a Kúriai Határozatok (korábban: Bírósági Határozatok) címủ folyóiratban közzétett eseti döntést csupán kettőt találunk ${ }^{2}$, sőt a 2020. év elején az időközben fokozott jelentőséget kapó Bírósági Határozatok Gyüjteményében is mindössze kilenc találatot adott a keresés (és ezek közül is csupán egy volt kúriai határozat). Ennek jelentős része volt abban, hogy az USA Külügyminisztériuma 2018-ban is úgynevezett megfigyelési listán tartotta Magyarországot, hivatkozással arra, hogy „, a magyar kormány nem teljesíti maradéktalanul az emberkereskedelem felszámolására vonatkozó minimumkövetelményeket, bár jelentös eröfeszitéseket tesz ennek érdekében" (URL2).

A jelentésből nem tünt ki, hogy annak készítői vizsgálták-e, és ha igen, miként értékelték az általuk emberkereskedelemnek tekintett cselekmények más büncselekményként - jellemzően kerítésként - való üldözését. Ugyanakkor az is tény, hogy az emberkereskedelem törvényi tényállása az eltelt több mint húsz évben többször is átszabásra került, amit a joggyakorlat nem feltétlenül kellő gyorsasággal követett, így feltételezhetően elsikkadt az, hogy a 2013. július 1. napján hatályba lépett Btk. számos új elkövetési magatartást is az emberkereskedelem tényállásába vont, és ezek már nem igényelték „kereskedelmi tranzakció" meglétét.

Úgy határoztunk, hogy a vizsgálat során feltárjuk, mi volt az oka az emberkereskedelem büntettével kapcsolatos ítélkezési gyakorlat korábbi zavarainak, hogyan alakult - folyamatában is - az elmúlt évek joggyakorlata, került-e sor emberkereskedelmi cselekmény miatt más büncselekmény miatt bünösség megállapítására, kellően ismerték-e fel a bíróságok a speciális, emberkereskedelem büntettekénti minősítést megalapozó tényállási elemeket. Ahogy arról már volt szó, a joggyakorlat elemzésével a módosult törvényi szabályozás várható hatásait is körvonalazhatónak láttuk. A kriminológus szakember bevonásával képet akartunk alkotni az emberkereskedelmi magatartások azon általános jellemzöiről is, aminek a jogalkotás során jelentősége van, és amit a jogalkalmazásnak is ismernie kell, és ugyanezen okból rövid nemzetközi kitekintést is kívántunk

2 Bírósági Határozat 2004.207. és Bírósági Határozat 2017.286. 
tenni a témában. Mindennek célja a joggyakorlat-elemzés következtetéseinek szélesebb alapokra való helyezése volt.

A joggyakorlat-elemzés alapját értelemszerüen a jogerős ítéletek képezik, amelyekből a bírói gyakorlat összetevődik. Az első feladatok egyike tehát annak az eldöntése volt, milyen jogerős határozatokat szerezzünk be az alsóbb fokú bíróságoktól. Mivel a kifejezetten emberkereskedelemként elbírált cselekmények száma igen csekélynek volt valószínüsíthető, előzetes terveinktől eltérően szükségesnek látszott - amennyire a nyilvántartások lehetővé teszik - egészen a tényállás 1999. évi megalkotásáig visszamenően valamennyi ilyen tárgyú ítélet beszerzése. Emellett elhatároztuk az összes olyan ügyben született jogerös itélet beszerzését, amelynek tárgyát olyan cselekmény képezte, ami időközben beolvadt az emberkereskedelem és kényszermunka tényállásába, illetve amelyek konkurálhatnak azzal, és ezért feltételezhető, hogy esetleg emberkereskedelmi cselekmény került más minősítéssel elbírálásra.

A fenti megfontolásokból a törvényszékektől és az ítélőtábláktól nem csupán az emberkereskedelem tárgyában született jogerős ítéleteket kértük be, hanem az elmúlt húsz évben hatályban volt szabályozás szerinti élősdi büncselekmények (kerítés, kitartottság, prostitúció - a korábbi szabályozás szerint: üzletszerü kéjelgés - elősegítése) miatt született döntéseket is. Az emberkereskedelem másik jellemző nagy területe kapcsán beszereztük a kényszermunka miatt meghozott jogerős ítéleteket, visszamenőlegesen a személyi szabadság megsértése munkavégzésre kényszerítés érdekében elkövetett minősített esetéig ${ }^{3}$. Ugyancsak beszereztük az emberi test tiltott felhasználásával összefüggésben meghozott jogerös ítéleteket is.

A határozatok 2020. év végéig megérkeztek a joggyakorlat-elemző csoporthoz. Az első feladat ezek szelektálása volt. Kiderült ugyanis, hogy jó pár határozat témánk szempontjából irreleváns, az emberkereskedelemmel való kapcsolódást nem vet fel. Azonban így is többszáz feldolgozandó határozatunk maradt. Ezért „kétkörös” megközelítést alkalmaztunk. Első lépcsőként az ügyeket felosztottuk és a csoport tagjai külön-külön dolgozták fel a rájuk eső ügyeket, kiemelve az egyes határozatokból a téma szempontjából fontos részeket. Második lépcsöként egy négytagú szükebb csoport, dr. Elek Balázs vezetésével „összegezte az összegzéseket”, kialakítva ezzel a jelentés anyagának gerincét.

Emellett számos önálló anyag is elkészült, melyek - a szélesebb megközelítés érdekében - szintén a jelentés részét képezik majd. A nemzetközi jogi kitekintést dr. Szabó Judit végezte el. Dr. Jancsó Gábor az újraszabályozás okairól és céljairól nyújtott betekintést a jogalkotó oldaláról. Dr. Windt Szandra az

3 1978. évi IV. törvény 175. § (2) bekezdés (hatályban volt 1999. március 1. napjától). 
emberkereskedelem kriminológiai, szociológiai jellemzői írt tanulmányt, míg az emberkereskedelemre vonatkozó büntető anyagi jogi szabályozás történeti fejlődéséről dr. Ignácz György írt, a Kúria tevékenységét az emberkereskedelmi ügyek kapcsán magam dolgoztam fel. Eközben a csoport két munkaülést is tartott online, 2021. április 9. és 2021. július 2. napján.

A jelentés anyaga tehát lényegében kész, de a jelentés még összeállításra vár. A csoport munkáját tagjainak leterheltsége és a fellángoló újabb járványhullámok továbbra is nehezítik. Ennek ellenére a csoport vezetője és tagjai mindent megtesznek annak érdekében, hogy a jelentés 2022 első negyedévében elkészüljön és a Kúria Büntető Kollégiuma a megtárgyalását követően elfogadja azt.

\section{Az emberkereskedelem szabályozásának változása és a gyakorlat alakulása}

Jelen írásom második részében szeretném röviden bemutatni az emberkereskedelem törvényi szabályozásának és bírói gyakorlatának változásait, ami reményeim szerint egyrészt megvilágíthatja az emberkereskedelem jogalkalmazásban való meggyökeresedése nehézségeinek okait, másrészt rámutat az előrevetíthető fejleményekre is, s mintegy a csoport munkájának hipotéziseit is jelentik. Az emberkereskedelem törvényi tényállásának az 1978. évi IV. törvénybe való beiktatásakor a törvény más személy eladását, megvásárlását, ellenszolgáltatás fejében való átadását, átvételét, más személlyel való elcserélése és e célra másnak megszerzését rendelte e címen büntetni. Ezeket nevezhetjük „,kereskedelmi aktusoknak" is; a kereskedés köznyelvi fogalmának is megfelel, ha eladunk, megveszünk, elcserélünk stb. valamit. 2002. április 1. napjától azonban a tényállás más, sui generis bünsegédi jellegü magatartásokkal egészült ki: emberkereskedelemként vált büntetendővé a toborzás, más szállítása, elszállásolása és elrejtése, feltéve, hogy arra a fenti elkövetési magatartások érdekében került sor. Az emberkereskedelem kezdeti elkövetési magatartásai tehát megfelelnek a kereskedés köznapi fogalmának, a sui generis bünsegédi magatartások pedig ehhez kapcsolódtak. Problémát okozott ugyanakkor, hogy a sértett feletti rendelkezés megszerzését - azaz az emberkereskedelmi cselekmény elkövetést - követően rendszerint újabb bűncselekmények történtek, sőt már a „kereskedelmi aktusra" is ennek érdekében került sor, jellemzően azért, hogy az elkövető a passzív alanyt futtassa, jogi nyelven: rendszeres haszonszerzés érdekében másoknak szexuális cselekmény végzésére szerezze meg. Az emberkereskedelem törvényi tényállása tehát ütközni látszott más, a magyar jogalkalmazásban mélyen gyökerező büncselekményekkel, jellemzően a kerítéssel és a kitartottsággal, 
később a kényszermunkával vagy más élősdi jellegü büncselekményekkel. A magyar jogi gondolkodás nehezen fogadta el, hogy maga a passzív alany feletti rendelkezés megszerzése - ami két személy egybehangzó akaratán alapszik és a passzív alanynak sincs feltétlenül ellenére - büncselekmény, de az azt követően megvalósult, büncselekmény törvényi tényállását kimerítő magatartás már nem. Ezért az emberkereskedelem kapcsán a jogalkalmazó kereskedelmi magatartást keresett: akkor látta megvalósultnak az emberkereskedelmet, ha kifejezetten kereskedelmi aktusra került sor, azaz az elkövető megvette, eladta stb. a sértettet. Jellemző, hogy az ebből az időszakból származó egyetlen közzétett eseti döntés sem kifejezetten a különös részi tényállással foglalkozott, hanem azt fejtette ki, hogy emberkereskedelem büncselekménye esetén társtettesség csak az azonos oldalon - a sértett eladásában, illetve megvásárlásában - közremüködő elkövetőknél állapítható meg. ${ }^{4}$

A 2012. évi C. törvény teljes egészében megőrizte a korábbi szabályozást, egy fontos ponton azonban ki is egészítette azt. A Btk. 192. § (2) bekezdése szerint az emberkereskedelem valamennyi korábbi elkövetési magatartás - a korábbi sui generis bünsegédi magatartások önmagukban, a „kereskedelmi” magatartáshoz való kapcsolódás nélkül is - büntetendővé váltak akkor, ha az elkövető kizsákmányolás célzatával valósította meg azt. Ezzel elvált az emberkereskedelem jogi és köznyelvi értelme, az emberkereskedelem elkövethetővé vált olyan magatartásokkal is, ami nem feleltethető meg köznyelvi értelemben vett kereskedelmi tevékenységben. Problémát jelentett azonban, hogy a kizsákmányolás - mint célzat - továbbra sem tartalmi meghatározást jelent; a kizsákmányolás nem önmagában, hanem valamilyen más tevékenységen keresztül valósul meg. Ezért, ha az önmagában is bűncselekmény (például kerítés, kényszermunka), a jogalkalmazó hajlamos volt továbbra is azt felismerni a kizsákmányolási célzat vizsgálata és értékelése helyett. Megint csak sokatmondó, hogy az ezen idöszakban közzétett eseti döntés is csupán arra vonatkozott, hogy amennyiben az enyhe és közepes fok határán álló gyengeelméjüségben szenvedő sértett megvásárlására külföldön végzendő prostitúciós tevékenység folytatása céljából került sor, az emberkereskedelem tényállási elemei maradéktalanul megvalósulnak ${ }^{5}$. Mindebből levonható az a következtetés, hogy a jogalkalmazás nehezen ismerte fel az emberkereskedelemnek új alakzataiban rejlő koncepcionális változást. Emberkereskedelem megállapítására többnyire olyankor került sor, amikor kifejezett adásvétel történt a passzív alany kapcsán. A változás akkor kezdődött, amikor - 2018. október 25-én - a Legfőbb Ügyészség új iránymutatást adott ki

4 BH 2014.217.

5 Bírósági Határozat 2017.286. 
a megyei föügyészségek és a fellebbviteli föügyészségek felé, amiben - nemzetközi jogforrásokat ${ }^{6}$ is elemezve - rámutatott arra, hogy az emberkereskedelem új törvényi tényállásának kulcsfontosságú eleme a kizsákmányolás, ami mind prostitúciós tevékenység kihasználásával, mind munkáltatással összefüggésben megvalósulhat. Ha pedig megvalósul, és az elkövető azzal összefüggésben az emberkereskedelem bármelyik, törvényben meghatározott elkövetési magatartását kifejti, úgy az emberkereskedelem valósul meg. Ez egyúttal azt is jelenti, hogy ilyenkor az elsőbbséget élvez az esetlegesen megállapítható más büncselekményekhez képest.

A már ezen iránymutatás alapján elöterjesztett ügyészségi felülvizsgálati indítványok nyomán a Kúria 2019. május 22-én hozta meg az első nagy jelentőségü döntését a tárgykörben ${ }^{7}$. Az ügyben irányadó tényállás lényege szerint az I. rendü terhelt fenyegetéssel kényszerítette a 13 éves sértettet arra, hogy az otthonául szolgáló gyermekotthont elhagyja, majd édesanyja lakásába vitte, ahol rendszeresen bántalmazta. A vádbeli napon a III. rendü terhelt felajánlotta az I. rendủ terheltnek, hogy 50000 forintot fizet neki, ha a sértett másnap közösül vele. A sértett közölte az I. rendü terhelttel, hogy ezt nem akarja, a terhelt azonban egy elhagyatott helyre vitte és ellenállásának megtörése végett bántalmazta a sértettet. Másnap a szexuális cselekményre sor került.

Az alapeljárásban meghozott jogerős ítéletében a bíróság mindkét terhelt bünösségét kerítés büntettében állapította meg e cselekmény kapcsán, a III. rendű terheltét mint felbujtóét. A Legfőbb Ügyészség indítványa arra irányult, hogy a Kúria állapítsa meg, miszerint a terheltek cselekményének helyes minősítése emberkereskedelem bűntette, és ezért - mivel az alapügyben az elsőfokú ítéletet a kerületi bíróság hozta meg - a jogerős ítéletet helyezze hatályon kívül és az illetékes törvényszéket utasítsa a megismételt eljárás lefolytatására.

A Kúria az indítványnak megfelelő határozatot hozott. Indokolásában rámutatott, hogy „, a kerités és az emberkereskedelem a »másnak megszerez« elkövetési magatartással egyaránt megvalósulhat. A kerités megállapitásához az szükséges, hogy a másnak megszerzés »haszonszerzés céljából szexuális cselekmény végzésére" történjék. Az emberkereskedelem megállapithatóságához pedig az szükséges, hogy a másnak megszerzés »kizsákmányolás céljából « történjék. [...] A másnak megszerzés tartalma alapvetően azonos a vizsgált két tényállásban. Ha tehát valaki elöny szerzése céljából megteremti a kiszolgáltatott helyzetbe

6 Az Európai Parlament és Tanács 2011/36/EU irányelvbe az emberkereskedelem megelőzéséről, és az ellene folytatott küzdelemről, az áldozatok védelméről, valamint a 2002/629/IB tanácsi kerethatározat felváltásáról. Az Egyesült Nemzetek keretében, Palermóban, 2000. december 14-én létrejött, a nemzetközi szervezett bünözés elleni egyezmény. Az Európa Tanács Emberkereskedelem Elleni Fellépésről szóló, Varsóban, 2005. május 16-án kelt egyezménye.

7 Bfv.II.1474/2018/9. 
hozott vagy helyzetben tartott, azaz kizsákmányolt passziv alany mással vagy másokkal történö szexuális kapcsolatának a közvetlen lehetöségét, a sértett megszerzésével az emberkereskedelem büntettét követi el". 8

A döntés jelentősége abban állt, hogy rávilágított arra, miszerint az emberkereskedelem elkövetési magatartását kimerítő cselekvőség megvalósulása esetén a kizsákmányolási célzattal való elkövetés „felülírja” az egyébként megvalósuló más büncselekményt és emberkereskedelemként való minősítéshez vezet, annak eljárásjogi következményeivel (hatáskör) együtt. A bíró feladata tehát, hogy amennyiben például „másnak megszerez” elkövetési magatartás kerül elébe, vizsgálja a passzív alany helyzetét. Amennyiben a passzív alany - bármilyen, akár az elkövetőn kívül álló okból - kiszolgáltatott helyzetben van (aminek fogalmát a törvény maga határozta $\operatorname{meg}^{9}$ ), úgy a kizsákmányolási célzat miatt a cselekmény emberkereskedelem, míg annak hiányában kerítés. Korábban szexuális cselekmény végzésére való másnak megszerzés esetén a sértett helyzetének vizsgálata fel sem merült, az - legalábbis a bünösség szempontjából - közömbös volt. Ezért a jogi közvéleményt a döntés kissé váratlanul érte ${ }^{10}$.

A Kúria másik gyakorlatformálónak szánt határozatát 2019. október 24-én Bfv.II.600/2019/13. szám alatt hozta meg, és az emberkereskedelem másik nagy ágát, a munkáltatással összefüggésben elkövetett emberkereskedelmet érintette. A bíróság jogerős ítéletében a három terhelt bünösségét - más, kapcsolódó testi épség, illetve szabadság és emberi méltóság elleni cselekmények mellett - többrendbeli kényszermunka büntettében állapította meg. Az irányadó tényállás szerint a terheltek az utcán léptek kapcsolatba különböző hajléktalan személyekkel, akiket könnyü munka ígéretével csábítottak magukhoz, és egy kamrából kialakított helyiségben szállásoltak el, majd pénzért koldultatták öket a városban és esetenként külföldön is.

A megyei föügyészség által előterjesztett és a Legfőbb Ügyészség által fenntartott indítvány ebben az esetben is arra irányult, hogy a Kúria állapítsa meg, miszerint a terheltek cselekménye emberkereskedelem, ezért az elsőfokon a járásbíróság által meghozott jogerős ítéletet helyezze hatályon kívül, és a törvényszéket kötelezze új elsőfokú eljárás lefolytatására.

8 Bfv.II.1474/2018/9.

9 2012. évi C. törvény 2020. július 1 . napja elött hatályos 192. § (8) bekezdés

10 Az ügy „utóélete” is érdekes. A megismételt eljárásban a bíróság az I. rendű terhelt bűnösségét emberkereskedelem bűntettében állapította meg, de az elsőfokú bíróság ítéletét a másodfokú bíróság hatályon kívül helyezte és új eljárás lefolytatását rendelte el, amiben még nem született jogerős ítélet. A III. rendű terhelt bűnösségét pedig jogerősen ismét felbujtóként elkövetett kerítés büntettében állapította meg azzal az indokolással, hogy e terhelt nem volt tisztában a sértett kiszolgáltatott helyzetével - Kúria Hkf. II.418/2021/8. és Bhar.II.420/2021/17. 
A Kúria ezúttal is az indítványnak megfelelö határozatot hozott, a jogi indokolást azonban nem lehetett teljes egészében a korábbi határozatban kifejtettek vázára felépíteni. A kényszermunka büntettének ugyanis az elkövetéskor hatályos szabályozás szerint ugyancsak a tényállási eleme volt a sértett kiszolgáltatott helyzetének kihasználása ${ }^{11}$, ez tehát önmagában nem lehetett az elhatárolás alapja.

A Kúria döntésének indokolása ebben az esetben is a tényállásszerüség vizsgálatán alapult. Rámutatott, hogy az ügyben a sértettek kiszolgáltatott helyzete kétségkívül megállapítható, mert „, a hajléktalan, családi és társadalmi kapcsolatokkal, valamint jövedelemmel nem rendelkezö, alacsony intellektusú és/ vagy testi fogyatékos, és ekként önmagát még csak alapszinten eltartani is csak korlátozottan képes személy kétségtelenül kiszolgáltatott helyzetben van". ${ }^{12} \mathrm{~A}$ kizsákmányolási célzat is fennállt, mert az „,nem vitathatóan anyagi elöny, hogy a terheltek a sértettek által koldulással megszerzett teljes keresményéhez csekély ellenszolgáltatás - azaz a pusztán a lakhatás és az élelmezés - szerény körülmények között való - biztositásával hozzájutottak. Egyúttal az a körülmény, hogy a sértettek teljes »szerzeményével « a terheltek rendelkeztek, és nekik saját rendelkezésükre álló pénzük egyáltalán nem maradt, kizárta, hogy a sértettek e kiszolgáltatott helyzetükböl kitörhessenek" "13.

Ezen túlmenően azonban a terheltek által tanúsított konkrét elkövetési magatartást is vizsgálni kellett. A Kúria kifejtette, hogy a kényszermunka megállapítására nem kerülhet sor, ha a kiszolgáltatott helyzetben lévő személy (vagy más személy erőszakkal vagy fenyegetéssel való) munkavégzésre kényszerítéséről van szó, mert e magatartás megfelel az emberkereskedelemnek a Btk. 192. § (1) és (2) bekezdésében meghatározott - valamely - elkövetési magatartásának is. A konkrét ügyben ,,adásvételre" nem került sor, a terheltek azonban toborozták, szállították és elszállásolták a kiszolgáltatott helyzetben lévő terhelteket, amivel az emberkereskedelem elkövetési magatartását merítették ki.

A Kúria ezen határozatában tehát olyan cselekmény kapcsán mondta ki azt, hogy a helyes minősítés emberkereskedelem büntette, amiben bármiféle kereskedelmi jellegü emberi magatartás fel sem merült. Határozatának alapja azonban a tényállásszerüség, ami dogmatikailag nehezen vitatható. Várható volt, hogy a Kúria bemutatott határozatai alapján a bírói gyakorlat is jelentős fordulatot vesz majd.

11 Btk. 2012. június 30. napja elött hatályos 193. § (1) bekezdés.

12 Bfv.II.600/2019/13.

13 Bfv.II.600/2019/13. 
Ebben a helyzetben döntött a Kúria elnöke az emberkereskedelem bírói értelmezésével kapcsolatos joggyakorlat elemzéséröl.

A joggyakorlat alapját azonban a jogalkotó határozza meg, és szinte pontosan egy időben ezzel a jogalkotó is a változtatás mellett döntött, és lényegében teljesen újraszabályozta az emberkereskedelem törvényi tényállását. Ennek okairól a jogalkotó tollából olvashatunk majd a jelentésben. De mi az, ami a gyakorló jogalkalmazónak feltünik az új tényállás kapcsán?

Megállapítható, hogy a hatályos Btk. 192. § (1) bekezdésében megmaradt a „hagyományos” emberkereskedelem, az 1999 óta létező elkövetési magatartásokkal. Az ilyen cselekmények száma azonban még az emberkereskedelmi ügyeken belül is csekély volt. Az igazi változást a (2) bekezdés tartalmazza. A tényállási elemek közül szinte teljesen eltünt a kizsákmányolás, ami a korábbi alakzat alapját jelentette és a Kúria is arra építette jogértelmezését. Ehelyett a cselekmény célzatává a rendszeres előnyszerzés lett, ami a továbbiakban kizárja, hogy egyszeri vagy alkalmi cselekmény - ha az elkövető szándéka sem irányult többre - e törvényhely szerint emberkereskedelmek minősüljön. Az előny tág fogalom, amibe nem csupán az anyagi haszon, ha bármi beletartozik, aminek révén az érintett - a passzív alany cselekvősége folytán - kedvezőbb helyzetbe kerül, mint elötte volt.

A konkrét elkövetési magatartás két nagy ágra bomlik: a rábírásra és a kényszerítésre, de a törvény meghatározza azok módjait is. Mindkét elkövetési magatartásban közös, hogy a rábírással, illetve kényszerítéssel elérni kívánt cél a passzív alany részéről munkavégzés, munka jellegü tevékenység végzése, egyéb szolgáltatás nyújtása vagy jogellenes cselekmény folytatásának kiváltása. Ez a meghatározás rendkívül tág, belefér minden olyan emberi tevékenység, aminek végzéséből az elkövető előnyhöz jut. Ez a rendkívül absztrakt meghatározás már félreérthetetlenül kifejezésre juttatja, hogy a tényállási elemek megléte esetén az emberkereskedelem megvalósulása szempontjából már közömbös a passzív alanynak az elkövető ráhatásával érintett magatartása, abba akár még a jogellenes cselekmény (így a büncselekmény, de más jogágakat sértö magatartás) is beletartozhat.

Az elkövetési magatartások közül a rábírás értelmezése elöreláthatólag kérdéseket vet majd fel a jogalkalmazásban. A rábírás a Btk. Általános Részében szerepel a felbujtás meghatározásában, mégsem mondhatjuk azt, hogy az az emberkereskedelem kapcsán is csak ugyanazt jelentheti, és csak akkor valósul meg, ha a passzív alany döntően e ráhatás eredményeképp tanúsítja a rábíró által elérni kívánt magatartást. Nagyon gyakori ugyanis, hogy a kiszolgáltatott helyzetben lévő passzív alanynak nincs más lehetősége, mint a kívánt tevékenység (például prostitúció, koldulás stb.) végzése, ezért maga is hajlandó arra, netán 
az emberkereskedővel való találkozása előtt is ugyanazt a tevékenységet végezte. Álláspontom szerint a rábírás a felbujtással az emberkereskedelem kapcsán azért sem azonosítható, mert a passzív alanynak a törvényi tényállásban írtaknak megfelelő cselekvősége korántsem csupán büncselekmény lehet, márpedig felbujtani csak büncselekmény és szabálysértés elkövetésére lehet. Ugyanakkor nemzetközi jogi normákból is fakadó alapvető elv, hogy a kiszolgáltatott helyzetben lévő sértett a szabadságát, emberi méltóságát sértő cselekmény elkövetésébe érvényes beleegyezést nem adhat, ekként a rábírás - ha az a törvényben meghatározott módok valamelyikén történik - megvalósulhat a sértett ellenkezésének hiányában, akár egyetértése mellett is.

Nem hagyható figyelmen kívül ennek kapcsán az sem, hogy a rábírás csak meghatározott módokon való elkövetés esetén felel meg a tényállásban meghatározott elkövetésnek. Az első ilyen elkövetési mód a megtévesztéssel való elkövetés. Ebben az esetben a passzív alany valamely lényeges körülmény ismerete nélkül, vagy az arra vonatkozó téves feltevésben (amit az elkövető váltott ki) cselekszik az elkövető akaratának megfelelően, esetleges szándéka, beleegyezése nem arra vonatkozik, ami ténylegesen történik majd, így nem tekinthető úgy, hogy a passzív alany szándéka eredetileg is arra irányult, azt nem az emberkereskedő váltotta ki. Megtévesztés esetén a felbujtás nem is értelmezhető. Ha tehát a prostituált úgy egyezik bele az emberkereskedő által kívánt tevékenységének végzésébe, hogy például munkakörülményeivel, az elvárt ,teljesítménnyel”, jövedelme elvonásának mértékével stb. nincs tisztában, azokra vonatkozóan az emberkereskedő megtéveszti, akkor közömbös, hogy maga is prostitúciós tevékenységet kíván végezni. De megállapítható a megtévesztés az úgynevezett „loverboy” elkövetés esetén is, azaz ha az elkövető magatartásával hamis érzelmi függésbe taszítja a sértettet, aki ennek hatására folytatja a tevékenységét az elkövető rendszeres előnyére.

A rábírás következő büntetendő módja a sértett nevelésével, felügyeletével, gondozásával, gyógykezelésével kapcsolatos, illetve a sértettel kapcsolatban fennálló egyéb hatalmi vagy befolyási viszonyával visszaélve történő elkövetés. Ezen tényállási elem már évek óta ismert a hatályos Btk. egyes nemi erkölcs és a nemi élet szabadsága elleni büncselekményeinek minősítő körülményeként, ekként bírói gyakorlata is kialakult. Érdemes felhívni a figyelmet arra, hogy a törvény nem pusztán az elkövető és a passzív alany közötti speciális viszony tényét, hanem az azzal való visszaélést, azaz a társadalmi rendeltetésének meg nem felelő tartalmú kihasználását határozza meg tényállási elemként. Ebben az esetben is arról van szó, hogy elegendő egy, az elkövető irányából kiinduló kezdeményezés a kívánt magatartásnak a terhelt előnyszerzése érdekében való tanúsítására, nem szükséges a döntő motívum kiváltása. 
Az érintettek közötti speciális viszony az esetleges beleegyezés önkéntességét önmagában kizárja.

Végül a rábírással elkövetett emberkereskedelem harmadik módja a kiszolgáltatott helyzet kihasználása; ennyiben használható marad a Btk. korábbi szabályozása alapján a Kúria bemutatott határozatai által alakított gyakorlat. Bár a törvény a kizsákmányolás fogalmát már nem határozza meg, azonban továbbra is irányadó az, hogy kiszolgáltatott helyzetben van, akinek ténylegesen nincs elfogadható választási lehetősége az emberkereskedő által célzott tevékenység végzése kapcsán, és az elkövető ennek kihasználásával törekszik előnyszerzésre. A kiszolgáltatott helyzet kapcsán annak oka és felróhatósága közömbös. Létrehozhatja azt az elkövető, de fennállhat tőle függetlenül is. Kiszolgáltatott helyzetben lévő személy beleegyezése ugyancsak nem lehet önkéntes, ezért a döntő motívum kialakítása ebben az esetben sem lehet a rábírás értelme.

Jóval kevesebb problémát vet majd fel várhatóan a másik elkövetési magatartás, a kényszerítés értelmezése. Az erőszak és a fenyegetés fogalma dogmatikailag kialakult, bírói gyakorlata következetes. Érdemes megjegyezni, hogy a törvény minősített erőszakot vagy fenyegetést nem kíván meg, azaz az emberkereskedelem akkor is megvalósul, ha az elkövető akaratot hajlító erőszakkal és nem élet vagy testi épség elleni közvetlen fenyegetéssel kényszeríti a sértettet a kívánt tevékenység végzésére.

A Btk. 193. § (3) bekezdése ezekhez az alakzatokhoz kapcsolja hozzá a már jól ismert „kereskedelmi jellegü” emberkereskedelmi és a sui generis bünsegédi jellegü cselekvőségeket: a toborzást, az átadást, az átvételt, az eladást, a megvásárlást, az elcserélést, az ellenszolgáltatásként átadást vagy átvételt, a másnak megszerzést, a szállítást, az elszállásolást, és az elrejtést. Fontos rámutatni azonban arra, hogy a (2) bekezdés szerinti büncselekmény ezek hiányában is megvalósul, míg a (3) bekezdésben felsorolt elkövetési magatartások csak akkor valósítják meg az emberkereskedelmet, ha azok olyan magatartáshoz kapcsolódnak vagy annak részei, amelyek a (2) bekezdésben foglalt elkövetési magatartások valamelyikét kimerítik. Ez lehet az elkövető saját magatartása (például azért vásárolja meg a sértettet, hogy utána megtévesztéssel prostitúcióra bírja rá), vagy másé is (azért szállítja a sértettet, hogy más erőszakkal munkavégzésre kényszerítse).

Vizsgáljuk meg még röviden a hatályos szabályozás által bevezetett minősítő körülményeket. Eszerint a minősítő körülmények három szinten helyezkednek el ${ }^{14}$, az első szintet követően két-két fokozatban, attól függően, hogy az alapesetre vagy az első szinten minősített esetekhez kapcsolódnak-e.

14 Btk. 192. § (4), (5) és (6) bekezdés. 
A Btk. 192. § (4) bekezdése minősített esetként határozza meg, ha a (2)-(3) bekezdés szerinti emberkereskedelmet szexuális cselekmény végzése, illetve az emberi test tiltott felhasználása érdekében követik el. A törvényhozó ezzel lényegében törvényi egységet teremtett az emberkereskedelem és a kerítés, illetve az emberi test tiltott felhasználásának egyes esetei között. Ez a megoldás orvosolhatja azt a korábban jelzett problémát is, hogy a korábbi szabályozás alapján az emberkereskedelem magába olvasztotta (külön értékelés nélkül hagyta) az azt követően megvalósított élősdi büncselekményeket, amit a magyar jogi gondolkodás nehezen fogadott el. E szabályozás révén az emberkereskedelmi cselekmény következtében megkezdett prostitúcióhoz kapcsolódó kerítői cselekvőség a minősítő körülményben értékelést nyer.

Az emberkereskedelem még súlyosabban minősülő esetei között a második szinten találjuk a tizennyolcadik életévét be nem töltött személy sérelmére, a sértett sanyargatásával és a hivatalos személyként, e minőséget felhasználva történő elkövetést. Ezek a Btk.-ból korábban már ismert fogalmak. Ugyanitt nyert azonban szabályozást a több ember sérelmére való elkövetés is, ami viszont komoly dogmatikai problémákat vet fel.

A több ember sérelmére való elkövetés minősítő körülményként való meghatározása úgynevezett összefoglalt büncselekményt képez, amit a törvényhozó általában azért alkalmaz, hogy a büncselekmény többszöri elkövetése esetén súlyosabb büntetéssel legyen fenyegetett, mint amit a halmazati szabályok eredményeznének ${ }^{15}$. Jelen esetben azonban nem ez a helyzet.

Speciális helyzetet eredményez ugyanis az, hogy a törvény az emberkereskedelemnek ennél súlyosabb minősítő körülményeit is meghatározza. Második szinten súlyosabban minősül ugyanis az emberkereskedelem, és így egyes esetekben akár életfogytig tartó szabadságvesztéssel is büntethető, ha azt tizenkettedik életévét be nem töltött személy sérelmére, avagy életveszélyt vagy különösen súlyos hátrányt okozva követik el.

A minősítő körülmények halmozódása esetén a rendező elv az, hogy az azonos büntetési tétellel fenyegetett minősítö körülmények egymás mellett állapítandók meg, míg az ugyanazon cselekményhez kapcsolódó súlyosabb minősítő körülmények kizárják az enyhébbek értékelését. Ha tehát az emberkereskedő legalább két sértett sérelmére követi el a cselekményét, a sértettek tizennyolcadik életévét be nem töltött életkora, a sértett sanyargatása és az elkövető speciális alanyi minősége a büntetési tétel szempontjából közömbössé válik; azonos

15 Jellemző példája ennek az emberölés. Több rendbeli alapeseti emberölés miatt az elkövető a halmazati szabályok szerint legfeljebb huszonkét év hat hónapi szabadságvesztéssel lenne büntethető, a több emberen való elkövetés minősítő körülményként való szabályozása azonban az életfogytig tartó szabadságvesztés kiszabását is lehetővé teszi. 
büntetési tétellel fenyegetett a két felnőttkorú sértett sérelmére, egyéb minősítő körülmény hiányában való elkövetés, és az akár több tucat vagy több száz 12-18 év közötti gyermek sérelmére megvalósított, esetleg más, azonos szinten szabályozott minősítő körülményt is kimerítő emberkereskedelem. Ugyanakkor ebből az egységből kimaradnak a még súlyosabban minősülő elkövetések. Így például több felnőttkorú személy és egy tizenkettedik életévét be nem töltött személy sérelmére való elkövetés, ha az egyik felnőtt sérelmére elkövetett cselekmény életveszélyt is okozott, összesen három rendbeli emberkereskedelemnek minősül, amiből egy rendbeli a Btk. 192. § (4) bekezdés d) pontja, egy rendbeli a (6) bekezdés a) pontja, egy rendbeli pedig a (6) bekezdés b) pontja szerint minősül.

\section{Záró gondolatok}

Nagyjából ennyi látható előre az új szabályozás alkalmazhatósága kapcsán. A joggyakorlat-elemző csoportnak - a müködési ideje alatt történt törvényváltozás következményeként - ezt is integrálnia kell a gyakorlatot feldolgozó jelentésébe, a kép csak ezzel lehet teljes. Néhány év elteltével mindenképpen érdemes lesz visszatekinteni, hogy a várakozások miként váltak be az emberkereskedelem bírói értelmezésének tükrében, szükség van-e akár a jogalkotó, akár a jogalkalmazó részéről újabb beavatkozásra.

\section{A cikkben szereplő online hivatkozások}

URL1: Emberkereskedelem. https://hu.wikipedia.org/wiki/Emberkereskedelem

URL2: Jelentés az emberkereskedelemröl-2018, USA Külügyminisztériuma. https://hu.usembassy. gov/wp-content/uploads/sites/232/jelent\%C3\%A9s-az-emberkereskedelemr\%C5\%911-2018hu. pdf

\section{Alkalmazott jogszabályok}

1978. évi IV. törvény a Büntető Törvénykönyvröl

2011. évi CLXI. törvény a bíróságok szervezetéről és igazgatásáról

2012. évi C. törvény a Büntető Törvénykönyvről

2020. évi V. törvény az emberkereskedelem áldozatainak kizsákmányolása elleni fellépés érdekében szükséges egyes törvények módosításáról 
Az Európai Parlament és a Tanács 2011/36/Eu irányelve (2011. április 5.) az emberkereskedelem megelőzéséröl, és az ellene folytatott küzdelemröl, az áldozatok védelméről, valamint a 2002/629/IB tanácsi kerethatározat felváltásáról 2006. évi CI. törvény az Egyesült Nemzetek keretében, Palermóban, 2000. december 14-én létrejött, a nemzetközi szervezett bünözés elleni egyezmény kihirdetéséről

Az Európa Tanács Emberkereskedelem Elleni Fellépésről szóló, Varsóban, 2005. május 16-án kelt egyezménye

Bfv.II.1474/2018/9.

Bírósági Határozat 2004.207.

Bírósági Határozat 2017.286.

Bírósági Határozat 2017.286.

\section{A cikk APA szabály szerinti hivatkozása}

Somogyi G. (2022). Betekintés a Kúria joggyakorlat-elemző munkacsoportjának munkájába. Belügyi Szemle, 70(2), 345-362. https://doi.org/10.38146/BSZ.2022.2.7 